\title{
The Multidimensionality of Cebuano Pronominals - Avenues for a Qualitative Investigation
}

\author{
Jennifer Tan-de Ramos \\ Department of English and Applied Linguistics, De La Salle University, Manila, Philippines \\ Email address: \\ jennifer.tan@dlsu.edu.ph \\ To cite this article: \\ Jennifer Tan-de Ramos. The Multidimensionality of Cebuano Pronominals - Avenues for a Qualitative Investigation. International Journal of \\ Language and Linguistics. Vol. 9, No. 4, 2021, pp. 221-225. doi: 10.11648/j.ij11.20210904.22
}

Received: July 18, 2021; Accepted: July 29, 2021; Published: August 5, 2021

\begin{abstract}
The study explores the properties of Cebuano pronominals in written discourse. Using Cebuano texts that are accessed online as its corpus, close textual analysis was done that aimed at determining the position of the pronouns in the clauses of written discourse. Findings reveal the dynamic nature of Cebuano pronominals in relation to the other morphological elements preceded or are followed by them. First, if the pronoun is attached to the verb, the position of the personal pronouns changes depending on the affix attached to the verb as the affix functions to denote the time the action was taken by the agent. Second, in terms of syntactic structure, Cebuano and English pronouns are similar. Third, the syntax of the personal pronouns is relative to the morphological unit these are attached to. In the case of a negative clause, deletion of the verb the initial pronoun follows is observed. Fourth, Cebuano pronominals are context-dependent rather than gender-determined. In sum, the findings open interesting avenues for students in Applied Linguistics to further investigate. For one, these observations may be explored individually using qualitative mechanisms of analyzing Cebuano pronominals and how they spell power relationships. Additionally, a contrastive analysis may be done between Cebuano pronominals and other Asian or Indo-European languages.
\end{abstract}

Keywords: Cebuano Pronominals, Experiencer, Subjective Case Pronouns, Objective Case Pronouns

\section{Introduction}

The Philippines is home to Filipinos who, because of the geographical separation among its 7,100 islands, speak different languages and dialects. To be specific, Tagalog is spoken by about 20 million Filipinos. The next predominant language is Cebuano (Visayan). Other languages are Ilocano, Hiligaynon, Bicolano, Waray-waray, Capampangan and Pangasinense.

Cebuano is an Austronesian language spoken in the Philippines by about 15 million people. Akin to languages like the Malaysian, Indonesian as well as other Filipino languages, Cebuano is spoken widely compared to other members of the Visayan languages. In fact, even if there is no educational institution in the Philippines that teaches Cebuano formally, it has the largest speaking population of the Philippines next to Filipino.

Research involving Cebuano language usually focuses on describing the grammatical and the syntactic features of the language. For example, Jubilado and Manueli [1] examine the components of the predicate and the temporal markings of the clause structures of the Malay and Cebuano languages using the Minimalist Syntax. Specifically, Cebuano data were derived from Cebuano speakers in the Davao Region. On the other hand, the Malay data came from Malay speakers at the Kuala Lumpur Federal Territory. The focus of analysis clause structures - are referred to as ditransitives, also known as triadic verbs.

Ditransitives are one type of predicate involving three arguments in its thematic structure. The findings reveal that analysis of the sentential constructions of the two languages provide two internal and one external arguments. Further analysis of the said languages, however, need to account for their differences in typology. While it is held that Cebuano maintains a predicate initial syntax, Malay observes a subject predominant syntax in its argument/thematic structure.

The basic notion here is that ditransitives are a type of transitive verbs with two objects, traditionally known as direct object and indirect object, in the domain of the VP structure. The two authors argue that, in the study of ditransitives, there is a need to delve more into the syntactic and semantic properties of this particular predicate type concerning 
computation where the arguments and theta roles are economically addressed. In particular, the syntactic phenomena are concerned with the case properties of arguments and the conditions associated with the assignment of case. Meanwhile, in Luzares' [2-3] study on Cebuano verb morphology and verb classification, Luzares uses a case grammar approach derived from Fillmore's [4] and Cook's [5] models which she extended and modified to suit her purpose. Using 1,400 verbs from a Cebuano dictionary, Luzares' analysis reveals two things about Cebuano verb morphology. One, Cebuano verb morphology is rule- governed. Two, the basis for verbal affixation has semantic underpinnings. Another study involving translation from Tagalog to Cebuano, Fat [6] took Roxas, Devilleres, and Giganto's [7] suggestion of implementing and evaluating the performance of the machine translator known as T2CMT. T2CMT is a machine translator specifically designed to translate words from Tagalog to Cebuano. To be able to do this, Fat had to develop a Tagalogto Cebuano dictionary, Using a four-step set of procedures that involved the use of $\mathrm{C}$ program and input of the Book of Genesis in the Tagalog version, the writer used an affix correspondence table to test the precision of translation from Tagalog to Cebuano affixes. The findings of the testing done on the machine translator revealed the following scores for average precision, recall and f-measure $-80.27 \%, 79.92 \%$, and $80.09 \%$ respectively. These scores fall beyond the range of good performance (19), which means that the system is able to perform well in translating the Book of Genesis from Tagalog to Cebuano. However, the most significant literature on Cebuano is on its pronominals done by Dita [8]. Her study describes the grammatical functions of pronominals in ten Philippine languages, the Cebuano language included. In this study that employs 100,000word- corpus for each language, Dita describes pronominals in Cebuano language as portmanteau pronouns. She describes this property as a combination of ergative and absolutive case- markings. In the ergative component, the first pronoun in the subject part of the clause acts as the agent and the latter pronoun in the predicate part acts as the patient in a clause. She further discloses that absolutives in the Cebuano pronominal system function as the sole arguments or experiencers in intransitive constructions or the object or patient in a transitive construction. Given the studies that explored Cebuano pronominals based on its structure and syntax in written discourse, this study aims to extend descriptions of Cebuano pronominals by determining their dynamic features in relation to the other morphological elements in the written texts and to suggest other areas in Applied Linguistics that researchers may venture into.

\section{Method}

The study used 50,946 word corpus of Cebuano texts that are accessed online. The first 44,086 Cebuano words were taken from the book of Genesis. The remaining words were derived from different genres also sourced online - poems, news and novelette. Analysis was done qualitatively on the position of the Cebuano pronominals in relation to affixes attached to the verbs. These affixes, particularly the prefixes, function to denote the time action was taken by the agent or the experiencer. Analysis also took into consideration the position of Cebuano pronouns in relation to other markers in a clause like the negative markers or the nouns the pronouns modify.

\section{Findings}

Several observations are noted regarding the position of the pronouns in relation to the other morphological components in the clause. First, if the pronoun is attached to the verb, the position of the personal pronouns changes depending on the affix attached to the verb as the affix functions to denote the time the action was taken by the agent As shown in table 1, the prefix mo- or mag-appears after the $2^{\text {nd }}$ person singular $k a$ to denote modality of the verb. On the other hand, the prefix nag- appears before the $1^{\text {st }}$ person singular ako to denote action done in the past.

Similarly, the prefix gi- appears before the $3^{\text {rd }}$ person singular siya to denote action done in the past. Additionally, the prefix manga- appears before the first person inclusive (ki)ta to denote future action. The prefix maka- appears before the first- person exclusive $(k a) m i$ to denote modality of the action. Next, the prefix maka- appears after the $2^{\text {nd }}$ person plural pronoun $(\mathrm{ka}) \mathrm{mo}$ to denote modality of action. All pronouns in these descriptions function as the agent of the clause.

Table 1. Subjective Case-Pronoun functions as the subject or agent of the clause.

\begin{tabular}{|c|c|c|c|c|c|}
\hline Number & Person & Cebuano pronoun & English pronoun & Sample sentence & English equivalent \\
\hline \multirow[t]{3}{*}{ Singular } & $1^{\text {st }}$ person & ako, (ako) & I & $\begin{array}{l}\text { Kay naghunahuna ako } \\
\text { (Genesis 20:11) }\end{array}$ & I said to myself \\
\hline & $2^{\text {nd }}$ person & ka, ikaw & You (singular) & dili ka magkaon niini (Genesis 2:17) & You must not eat from any tree \\
\hline & $3^{\text {rd }}$ person & Siya & he, she & $\begin{array}{l}\text { Ug gikuha ni jehova nga Dios ang tawo ug } \\
\text { gibutang siya tanaman sa Eden Genesis } \\
2: 15)\end{array}$ & $\begin{array}{l}\text { And the Lord God took the man } \\
\text { and he put him in the Garden of } \\
\text { Eden }\end{array}$ \\
\hline Number & Person & Cebuano pronoun & English pronoun & Sample sentence & English equivalent \\
\hline \multirow[t]{4}{*}{ Plural } & $\begin{array}{l}1^{\text {st }} \text { person (including } \\
\text { person being spoken to) }\end{array}$ & (ki)ta & we (inclusive) & manganaug kita (Genesis 11:7) & We will go down \\
\hline & $\begin{array}{l}1^{\text {st }} \text { person (excluding } \\
\text { person being spoken to) }\end{array}$ & (ka)mi & we (exclusive) & $\begin{array}{l}\text { Makakaon kami sa bunga sa mga kahoy sa } \\
\text { tanaman: (Genesis } 3: 2)\end{array}$ & $\begin{array}{l}\text { We may eat fruit from the trees in } \\
\text { the garden }\end{array}$ \\
\hline & $2^{\text {nd }}$ person & (ka)mo & you (plural) & $\begin{array}{l}\text { Dili kamo makakaon sa tanan nga mga } \\
\text { kahoy sa tanaman? (Genesis } 3: 1 \text { ) }\end{array}$ & $\begin{array}{l}\text { You must not eat from any tree } \\
\text { in the garden? }\end{array}$ \\
\hline & $3^{\text {rd }}$ person & Sila & They & $\begin{array}{l}\text { Ug ginapanalanginan sila sa Dios } \\
\text { (Genesis } 1: 21)\end{array}$ & $\begin{array}{l}\text { And they were blessed by the } \\
\text { Lord }\end{array}$ \\
\hline
\end{tabular}


Second, similar to the English syntactic structure of DET + NOUN, Cebuano pronouns that function as determiner in the experiencer part of the clause, regardless of their number, are positioned before the nouns they modify. This observation is true for all persons- $1 \mathrm{st}, 2 \mathrm{nd}$, and $3 \mathrm{rd}$. Table 2 displays sample texts taken from Cebuano Bible. For example, ang akong nasud has the first person singular personal pronoun in the experiencer part of the clause acting as determiner. In
English, a personal pronoun also functions as a possessive determiner. The grammatical function of a possessive determiner is to indicate possession of or some other relationship to the noun. Some possessive determiners in English are my, your, his, her, its, our, and their and the interrogative possessive determiner whose [9]. Likewise, the second person singular imong is followed by the noun tinguha that it modifies in the subject part of the clause.

Table 2. Pre-possessive Case-Pronoun functions as determiner in the subject part of the Clause.

\begin{tabular}{|c|c|c|c|c|c|}
\hline Number & Person & $\begin{array}{l}\text { Cebuano } \\
\text { Pronoun }\end{array}$ & $\begin{array}{l}\text { English } \\
\text { Pronoun }\end{array}$ & Sample Sentence & English Equivalent \\
\hline Singular & $1^{\text {st }}$ person & $\begin{array}{l}\text { ako, } \\
\text { akong }\end{array}$ & mine, my & Akong nasud ang akong katabang sa pag asenso & $\begin{array}{l}\text { My nation aids in my } \\
\text { development }\end{array}$ \\
\hline \multirow{6}{*}{ Plural } & $2^{\text {nd }}$ person & $\begin{array}{l}\text { imo, } \\
\text { imong }\end{array}$ & $\begin{array}{l}\text { yours, your } \\
\text { (singular) }\end{array}$ & $\begin{array}{l}\text { ug ang imong tinguha mao ang pagpangandoy sa } \\
\text { imong bana.(Genesis } 3: 16 \text { ) }\end{array}$ & $\begin{array}{l}\text { Your desire will be for } \\
\text { your husband }\end{array}$ \\
\hline & $3^{\text {rd }}$ person & iya, iyang & his, her, hers & Maoy iyang desisyon nga makuha siya & \\
\hline & $\begin{array}{l}1^{\text {st }} \text { person (including } \\
\text { person being spoken to) }\end{array}$ & ato, atong & $\begin{array}{l}\text { ours, our } \\
\text { (inclusive) }\end{array}$ & $\begin{array}{l}\text { Kay maoy maghatag balaka ug aliwaros sa atong } \\
\text { kalag (Ang pagkab-ot sa tinood nga kalipay By } \\
\text { Genamos_US of Washington DC, USA, p. 122) }\end{array}$ & \\
\hline & $\begin{array}{l}1^{\text {st }} \text { person (excluding } \\
\text { person being spoken to) }\end{array}$ & $\begin{array}{l}\text { amo, } \\
\text { among }\end{array}$ & $\begin{array}{l}\text { Ours, our } \\
\text { (exclusive) }\end{array}$ & Among balay kami nagdeskanso & \\
\hline & $2^{\text {nd }}$ person & $\begin{array}{l}\text { inyo, } \\
\text { inyong }\end{array}$ & $\begin{array}{l}\text { Yours, your } \\
\text { (plural) }\end{array}$ & $\begin{array}{l}\text { Kay hingbaloan sa Dios, nga sa adlaw nga kamo } \\
\text { mokaon niini mangabuka ang inyong mga mata } \\
\text { (Genesis } 3: 5 \text { ) }\end{array}$ & \multirow{2}{*}{$\begin{array}{l}\text { For God knows that when } \\
\text { you eat of it, your eyes } \\
\text { will be opened } \\
\text { Their livestock is what } \\
\text { they took with them }\end{array}$} \\
\hline & $3^{\text {rd }}$ person & ila, ilang & Theirs, their & Ilang kahayupan ang ilang gidala (Genesis 46:6) & \\
\hline
\end{tabular}

Third, if the pronoun examined is positioned in the predicate part of the clause, the personal pronoun syntax is relative to the other morphological unit it is attached to. If the personal pronoun attached to the noun functions as descriptor or modifier in the predicate part of the clause, the pronoun examined appears after the noun it modifies and before the verb that qualifies the noun. This is observed in na ang balay nako nasunog. However, if the initial pronoun functions as both agent and patient in the negative clause, the verb the initial pronoun follows is deleted. Moreover, the negative marker dili is placed at the head of the clause followed by the two pronouns nimo and siya appearing one after the other.
Here, nimo as the agent and siya as the patient refer to the same person. It is also observed that Cebuano pronouns do not recognize the gender of the agent. In fact, when translated, the first clause may also refer to she. This is unlike Arabic pronouns [10], as cited in [11]. This phenomenon is noted in the following examples:

(1) Dili nimo siya anak. (He is not your son.)

(2) Dili nato sala.(It was not our mistake.)

In the second clause, not only is the verb omitted, the personal pronoun it when used in the subject part of the clause is likewise deleted. More examples are found in Table 3.

Table 3. Post-possessive Case-Pronoun functions as possessing something in the predicate part of the sentence.

\begin{tabular}{|c|c|c|c|c|c|}
\hline Number & Person & $\begin{array}{l}\text { Cebuano } \\
\text { Pronoun }\end{array}$ & English Pronoun & Sample Sentence & English Equivalent \\
\hline \multirow[t]{3}{*}{ Singular } & $1^{\text {st }}$ person & nako & my & Gisultihan kita na ang balay nako nasunog & $\begin{array}{l}\text { I told you that my house got } \\
\text { burned. }\end{array}$ \\
\hline & $2^{\text {nd }}$ person & nimo, & Your (singular) & Dili nimo anak siya & He is not your son. \\
\hline & $3^{\text {rd }}$ person & niya, & his, her & $\begin{array}{l}\text { Tungod kay niini nagpahulay siya gikan sa } \\
\text { tanan niyang buhat nga gibuhat ug nahimo sa } \\
\text { Dios. (Genesis } 2: 3 \text { ) }\end{array}$ & $\begin{array}{l}\text { Because of this, He rested } \\
\text { from all his works. }\end{array}$ \\
\hline \multirow[t]{4}{*}{ Plural } & $\begin{array}{l}1^{\text {st }} \text { person (including } \\
\text { person being spoken to) }\end{array}$ & nato & Our (inclusive) & Dili nato sala & It was not our mistake \\
\hline & $\begin{array}{l}1^{\text {st }} \text { person (excluding } \\
\text { person being spoken to) }\end{array}$ & namo & our (exclusive) & $\begin{array}{l}\text { nga giablihan namo ang among mga baluyot } \\
\text { (Genesis } 43: 21 \text { ) }\end{array}$ & We opened our baskets \\
\hline & $2^{\text {nd }}$ person & ninyo & Your (plural) & $\begin{array}{l}\text { Paanhion ninyo ang inyong igsoon nga lalake? } \\
\text { (Genesis } 43: 7 \text { ) }\end{array}$ & $\begin{array}{l}\text { Bring your brother down } \\
\text { here? }\end{array}$ \\
\hline & $3^{\text {rd }}$ person & nila & their & Balay nila kini & This is their house \\
\hline
\end{tabular}

Fourth, Cebuano pronominals do not realize the gender of the agent and the patient in the subjective case as well as the objective case pronouns respectively. Gender determination is based on the context $[12,13]$ the text was taken. For instance, in table 4, reference to (ka)nimo as second person singular is realized as pointing to a male persona because the 
reader knows that the text is Genesis of the Bible. Further, the reader recognizes that the speaker is God addressing Abraham. Furthermore, the objective case third person singular pronoun (ka)niya is realized as referring to a male persona since the initial personal pronoun siya in pagabuhatan ko siya ug katabang nga angay kaniya points to Adam in Genesis when God was referring to His creation of a companion fit for Adam. It is observed that the object siya of the transitive verb is deleted upon translation into English.

In terms of position, Cebuano objective case pronouns are positioned at the last part of the clause that they were referred to. Similar to the English translation, Cebuano case pronouns are preceded by the verbs, Cebuano language, being most often a verb-first language $[14,15]$. It is observed that if the objective case pronouns are preceded by prepositions, the prepositions are deleted. This is observed in nakapabasul kanako translated as 'mistake to me', angay kaniya, translated as 'fit for him', and namakak ang tawo kanamo, translated as 'the man lied to us'.

Table 4. Objective Case - Pronoun functions as object of the sentence.

\begin{tabular}{|c|c|c|c|c|c|}
\hline Number & Person & $\begin{array}{l}\text { Cebuano } \\
\text { Pronoun } \\
\end{array}$ & $\begin{array}{l}\text { English } \\
\text { Pronoun }\end{array}$ & Sample Sentence & English Equivalent \\
\hline \multirow[t]{3}{*}{ Singular } & $1^{\text {st }}$ person & (ka)nako & me & $\begin{array}{l}\text { Kay kini nakapabasul kanako nga gibuhat ko sila } \\
\text { (Genesis6:7) }\end{array}$ & It was a mistake to me. \\
\hline & $2^{\text {nd }}$ person & (ka)nimo, & you (singular) & $\begin{array}{l}\text { Ug akong pagabuhaton kanimo ang usa ka daku } \\
\text { nga nasud (Genesis 12:2) }\end{array}$ & $\begin{array}{l}\text { And I will make you a great } \\
\text { nation. }\end{array}$ \\
\hline & $3^{\text {rd }}$ person & (ka)niya, & him, her & $\begin{array}{l}\text { pagabuhatan ko siya ug katabang nga angay } \\
\text { kaniya. (Genesis } 2: 18 \text { ) }\end{array}$ & $\begin{array}{l}\text { I will make a companion fit } \\
\text { for him. }\end{array}$ \\
\hline \multirow[t]{4}{*}{ Plural } & $\begin{array}{l}1^{\text {st }} \text { person (including } \\
\text { person being spoken to) }\end{array}$ & (ka)nato & us (inclusive) & $\begin{array}{l}\text { Ug minos-minos pa kanato (Ang pagkab-ot sa } \\
\text { tinood nga kalipay By Genamos_US of } \\
\text { Washington DC, USA, p. 122) }\end{array}$ & It cheapens us. \\
\hline & $\begin{array}{l}1^{\text {st }} \text { person (excluding } \\
\text { person being spoken to) }\end{array}$ & (ka)namo & us (exclusive) & Namakak ang tawo kanamo & The man lied to us. \\
\hline & $2^{\text {nd }}$ person & (ka)ninyo & you (plural) & $\begin{array}{l}\text { ug kini mao ang timaan sa saad sa taliwala kanako } \\
\text { ug kaninyo (Genesis 17:11) }\end{array}$ & $\begin{array}{l}\text { This is the sign of the } \\
\text { covenant between me and } \\
\text { you }\end{array}$ \\
\hline & $3^{\text {rd }}$ person & (ka)nila & them & $\begin{array}{l}\text { Kini mao ang mga sinugdan sa mga langit ug sa } \\
\text { yuta, sa pagbuhat kanila (Genesis } 2: 4)\end{array}$ & $\begin{array}{l}\text { This is the beginning of } \\
\text { heaven and earth, in creating } \\
\text { them }\end{array}$ \\
\hline
\end{tabular}

\section{Conclusion}

In summary, the paper has provided a qualitative analysis of Cebuano pronominals based on the corpus of Cebuano words accessed online. Findings reveal the phenomenon of variation of pronoun positioning relative to the action denoted by the verb. Additionally, pronouns in the subjective case of the clause function in duality - as possessive determiner and as personal pronoun. Also, if the pronoun is followed by the verb in the subjective case of the clause, the property of verb deletion occurs. For negative clauses that begin with It, the Cebuano negative marker dili is positioned at the head of the clause while it is deleted Finally, Cebuano do not recognize gender both $t$ in the subjective and the objective case of the clause. Instead, gender recognition is based on context. What the findings show are the many dimensions that the Cebuano pronominal system can be looked at. This study is significant to students of applied linguistics who believe that analysing the structures of a given language will open interesting dimensions to the existing studies that have been done about it. To end, future studies on Cebuano pronominals may look into the phenomenon of power relationships residing in their contexts of use.

\section{Acknowledgements}

This paper is dedicated, in loving memory, to Julieta $B$. Tan, my mother, who helped me translate the Visayan texts.
For this, among others, I am greatly indebted.

\section{References}

[1] Rodney C. Jubilado, R. C. \& Maria Kristina Manueli. Malay and Cebuano ditransitives: A minimalist perspectives. Journal of Modern Languages, 2009 (19): 1-14, https://ejournal.um.edu.my/index.php/JML/article/view/3617.

[2] Casilda Edrial Luzares. Cebuano verb morphology: An application of case grammar, part 1. Studies in Philippine Linguistics, 1977 (1) 2: 73-109. Retrieved 2 April 2011 from http://www.sil.org/asia/philippines /sip1/SIPL_1-2_073-109.pdf.

[3] Casilda Edrial Luzares. Cebuano verb morphology: An application of Case grammar, part 2. Studies in Philippine Linguistics, 1978 (2) 1: 49-72.

[4] Charles Filmore. The case for case. Universals in Linguistics Theory ed. by Emmon Bach \& Robert Harms, 1-88. New York: Holt, Rinehart and Winston, 1968.

[5] Walter Cook. Case grammar: From roles to rules, Georgetown University Languages and Linguistics Papers, 1. Georgetown, USA, 1970.

[6] Fat, J. G. T2CMT: Tagalog-to-Cebuano Machine Translation. Master's Thesis, De La Salle University, 2004.

[7] Rachel E. Roxas, Devilleres, E. \& Reynaldo T. Giganto. Computational representation of Philippine dialects: Towards a multilingual mt. 38th Annual Conference of the Association for Computational Linguistics, Hongkong, October 1-8, 2001. 
[8] Shirley N. Dita. A morphosyntactic analysis of the pronominal system of Philippine languages. The 24th Pacific Asia Conference on Language, Information and Computation, Tohoku University, Sendai, Japan, 1998.

[9] Possessive determiners. Retrieved 5 April 2011 from http://www.brighthub.com/education/languages/articles/36828 .aspx\#ixzz1lffQ.

[10] 1 (Al-LaHyany, 2002 Al-LaHyany, Z. (2002). Cases of pronouns with their Interpreters. Unpublished MA. Thesis, University of umalqura, Saudi Arab Kingdom. Al-Laymuun, A (2010). Emphasis Style in.

[11] Zainab Kadim Igaab1 \& Intisar Raham Tarrad. Pronouns in English and Arabic: A Contrastive Study. English Language and Literature Studies, 2019 (9) https://www.researchgate.net/publication/330708268_Pronoun s_in_English_and_Arabic_A_Contrastive_Study.
[12] Stojnić, Una, Matthew Stone, \& Ernie Lepore. "Discourse and Logical Form: Pronouns, Attention and Coherence." Linguistics and Philosophy, 2017 40. 5: 519-47. Accessed July 27, 2021. http://www.jstor.org/stable/45106835.

[13] Mieko Ueno \& Andrew Kehler. Grammatical and pragmatic factors in the interpretation of Japanese null and overt pronouns. Linguistics, 2016 (54) 6: 1165-1221. https://doi.org/10.1515/ling-2016-0027.

[14] Ava T. Parnes. Ang marks the what?: An analysis of noun phrase markers in Cebuano, 2011. https://ling.yale.edu/sites/default/files/files/alumni\%20senior \%20essays/Ava\%20Tattleman\%20Parnes.pdf.

[15] Billings, Loren A. Ordering clitics and postverbal Rexpressions in Tagalog. In Andrew Carnie, Heidi Harley, \& Sheila Ann Dooley (eds.), Verb first: On the syntax of verbinitial languages, 303-339. Amsterdam/Philadelphia: John Benjamins Publishing Company, 2005. 